FOLIA HISTORICA CRACOVIENSIA, 22: 2016, s. 157-172

DOI: http://dx.doi.org/10.15633/fhc.2077

Ewa Korpysz

Muzeum Archidiecezji WarszawsKiej

\title{
Zmiany w wyposażeniu architektoniczno-rzeźbiarskim klasztoru czerwińskiego w pierwszej połowie XVI wieku
}

Wzniesione przed połową XII wieku kościół i klasztor kanoników regularnych lateraneńskich w Czerwińsku, fundacja biskupa płockiego Aleksandra z Malonne, już w średniowieczu zaliczały się do najprzedniejszych i najbardziej okazałych na Mazowszu ${ }^{1}$ (il. 1). Dwuwieżowa bazylika z pseudotranseptem, prezbiterium wyodrębnionym, zamkniętym absydą oraz wnętrzem rozdzielonym zmiennym systemem murowanych podpór, reprezentuje tzw. nurt tradycjonalny w romańskiej architekturze Polski². W kościele wyróżniała się bogata dekoracja portalu głównego, kontrastująca z surowością architektury budowli.

Pierwsze przekształcenia siedziby konwentu były związane prawdopodobnie z nadaniami Konrada Mazowieckiego ok. 1221-1222 roku i objęły część wschodnią południowej nawy kościoła. Z kolei w 1279 roku prowadzono prace w budynkach klasztoru. W 1328 roku kościół uległ pożarowi, po którym, w końcu tego stulecia i początkach następnego, nastąpiła odbudowa świątyni. W jej wyniku wnętrze uzyskało gotycki charakter. Z kolei za czasów opata Rafała (1497-1502) zmianie ulega partia międzywieżowa. Z końca XV wieku pochodzi gotycki refektarz w skrzydle południowym, przekryty gwiaździstym sklepieniem wspartym na konsolach.

\footnotetext{
Zob. T. Mroczko, Czerwińsk romański, Warszawa 1972, s. 6. Na temat kościoła Kanoników Regularnych w Czerwińsku patrz też: Polska sztuka przedromańska i romańska do schyłku XIII wieku, t. 1, red. M. Walicki, Warszawa 1971, s. 127; t. 2, s. 681-682; Katalog zabytków sztuki w Polsce, t. 10: Dawne województwo warszawskie, z. 16: Płońsk i okolice, oprac. I. Galicka, H. Sygietyńska, T. Mroczko, Warszawa 1979, s. 7-31; T. Mroczko, Polska sztuka przedromańska i romańska, Warszawa 1988, s. 69-71; Z. Świechowski, E. Świechowska, Polska sztuka romańska, Warszawa 2006, s. 70-72; J. Nowiński, Czerwińsk, Warszawa 2012.

2 Zob. T. Mroczko, Polska sztuka..., dz. cyt., s. 69-71.
} 
Następną przebudowę, przebiegającą już w duchu nowego stylu, zainicjował Jakub Kula, opat czerwiński w latach $1524-1538^{3}$. Jakub Kula z Soboli, herbu Roch III, prepozyt w Błoniu, w dniu 24 maja 1524 roku został opatem w Czerwińsku, zaś 4 czerwca tego roku przyjął godność kanonika kapituły katedralnej i kolegiackiej św. Michała w Płocku. Jego działalność jest ciągle mało rozpoznana, ale w świetle dostępnych dziś materiałów archiwalnych jawi się on jako osoba przedsiębiorcza i operatywna ${ }^{4}$. Jak obwieszcza inskrypcja na epitafium w kościele, był to „mąż bogobojny niezwykłej obserwancji, naturalnej prostoty, gdy podjął się niezwykłych wydatków i prac przy powiększaniu klasztoru, umarł z wyczerpania w 1538 roku od Odkupienia"s.

Ta wyczerpująca zdrowie działalność opata przejawiała się w trosce o interesy ekonomiczne konwentu i wiązała $\mathrm{z}$ koniecznością prowadzenia nieustannych zabiegów dyplomatycznych i negocjacji z biskupami płockimi, dotyczących spraw majątkowych klasztoru. Kula dążył do skupienia w jednym kluczu posiadłości klasztornych, planował korzystne zamiany gruntów i transakcje z biskupem płockim oraz kapitułą katedralną ${ }^{6}$.Zdobywał dla zakonu przywileje królewskie i książęce, ułatwiające konwentowi prowadzenie działalności handlowej. Pozyskiwane środki opat przeznaczał na odbudowę i wyposażenie klasztoru i kościoła. Plan robót budowlanych musiał być szeroki, ale, jak z treści jego epitafium wynika, Jakub Kula „nie ukończył nakładów i prac w przyozdobieniu klasztoru podjętych”"

$\mathrm{W}$ zakres robót prowadzonych za czasów opata wchodziło m.in. założenie sklepień $w$ kościele ${ }^{8}$. Prawdopodobnie wtedy też przedzielono murem kaplicę północną i w jej wschodniej części usytuowano skarbiec. Około roku 1530 Hans Dürer wykonał w absydzie prezbiterium polichromię o motywach roślinnych i figuralnych (głowy w wieńcach laurowych i popiersia apostołów $\mathrm{z}$ atrybutami) ${ }^{9}$. Z kolei w refektarzu klasztornym żebra trzech przęseł sklepienia zostały pokryte dekoracją malarską w formie wici liściastej (zamalowaną w XvıI wieku i odsłoniętą w trakcie prac konserwatorskich w latach 1928-1930 ${ }^{10}$.

3 Zob. T. Mroczko, Czerwińsk..., dz. cyt., s. 11.

4 Zob. H. Folwarski, Poczet opatów klasztoru kanoników regularnych w Czerwińsku, „Nasza Przeszłość. Studia z Dziejów Kościoła i Kultury Katolickiej w Polsce” Kraków, 6 (1957), s. 21.

5 Epitafium zostało ufundowane przez opata Mikołaja Szyszkowskiego między rokiem 1621 a 1633. Por. Katalog zabytków..., dz. cyt., s. 162.

6 Zob. H. Folwarski, Poczet..., dz. cyt., s. 22.

7 T. Mroczko, Czerwińsk..., dz. cyt., s. 11.

8 Zob. H. Folwarski, Poczet..., dz. cyt., s. 22; J. Nowiński, Czerwińsk, dz. cyt., s. 48.

9 Zob. J. Nowiński, Czerwińsk, dz. cyt., s. 48.

10 Zob. J. Nowiński, Czerwińsk, dz. cyt., s. 88. 
Z okresem urzędowania opata Kuli wiąże się też powstanie w kościele i klasztorze kamiennych obramień i portali, zachowanych do dziś bądź w miejscach pierwotnego przeznaczenia lub wmurowanych wtórnie albo też istniejących $\mathrm{w}$ formie luźnych kamiennych elementów w lapidarium klasztornym. $\mathrm{Z}$ dawnego renesansowego portalu prowadzącego z prezbiterium do zakrystii przetrwał jedynie fragment wschodniego ościeża, włączony we wczesnobarokowy portal z czasów opata Mikołaja Szyszkowskiego $(1622-1634)^{11}$. Do dziś zachował się natomiast portal ujmujący wejście do refektarza w południowym skrzydle budynku klasztornego. Portal ten, uważany za „pierwszy, bardzo zresztą skromny przejaw renesansu w architekturze na obszarze Mazowsza" ${ }^{12}$, ma cechy gotycko-renesansowe. Proporcje jego obudowy są ciężkie, detal mało finezyjny i oszczędny, profile grube i niezgrabne, przypominające raczej laskowania niż formy antyczne. W dekoracji zastosowano późnogotycki motyw skręconego sznura. W nadprożu widnieje inskrypcja z datą 1529 i nazwiskiem Jakuba Kuli (il. 2).

Motywy gotyckie sąsiadujące z renesansowymi znajdują się również w innych, zachowanych w kościele i klasztorze fragmentach kamieniarki z czasów opata Kuli. Jest wśród nich nadproże z gotyckim napisem dotyczącym opata i z herbem Roch III, wmontowane pod wieżą kościoła (il. 3). Z tego czasu pochodzą też relikty wtórnie użyte jako obudowa kominka w jednym z pomieszczeń południowego skrzydła klasztoru (il. 4). Wygląd omawianych fragmentów, rzeźbionych nieprecyzyjnie, niekiedy bez zrozumienia, świadczy, że opat do wykonania obramień portalowych zaangażował kamieniarzy o przeciętnych możliwościach.

W klasztornym lapidarium można też jednak odnaleźć rzeźbione elementy kamienne o zupełnie innej stylistyce. Należą do nich bardzo już dziś zniszczone pozostałości kamiennej oprawy architektoniczno-rzeźbiarskiej o niejasnym przeznaczeniu. Wśród zachowanych szczątków znajduje się część płyty z wyrzeźbionym Barankiem w nimbie, leżącym na księdze i zbierającym krew do kielicha (il. 5a, b). Ponadto ocalały niewielkie luźne fragmenty pilastrów dekorowanych arabeską w układzie kandelabrowym (il. 6). Autorki Katalogu zabytków uznały je za relikty sakramentarium i zadatowały na trzecią dekadę Xvi wieku ${ }^{13}$.

Wymienione detale znajdują się dziś w dużo gorszym stanie niż wówczas, kiedy odnalazły je inwentaryzatorki ${ }^{14}$. W ocenie i opisie zniszczonego zabytku jest po-

${ }^{11}$ Zob. Katalog zabytków..., dz. cyt., s. 13.

${ }_{12}$ J. Szablowski, Architektura renesansowa i manierystyczna w Polsce, Kraków 1965, s. 17.

13 Zob. Katalog zabytków..., dz. cyt., s. 25.

${ }^{14}$ Omawiane szczątki oprawy były oglądane przeze mnie w 2006 roku. Leżały wówczas w nieładzie na posadzce wśród fragmentów innych zabytków kamieniarki. Detale wykonane z miękkiego i podatnego na kruszenie wapienia były ustawicznie narażone na obtłuczenia. Trudności, jakie 
mocne porównanie zachowanych reliktów z dawnymi fotografiami, wykonanymi w trakcie ewidencji przeprowadzanych na potrzeby Ośrodka Dokumentacji Zabytków (obecnego Narodowego Instytutu Dziedzictwa) oraz Katalogu zabytkó $w^{15}$ (il. 5b).

Wizerunek Baranka ujmowało nieistniejące już, półkoliste, profilowane obramienie o przekroju półwałka, nadające tej części płyty charakter tympanonu. Bezpośrednio pod jego dolną krawędzią zachowały się ślady drugiego, poziomego oprofilowania z motywem simy, tworzącego niegdyś prostokątną ramę, okalającą płycinę, której resztki zachowały się poniżej. W tym samym fragmencie kamienia był wykuty pilaster, flankujący kompozycję po lewej stronie. Podczas ostatnich oględzin ten detal już nie istniał. Dzięki dawnej fotografii i zachowanym, luźnym reliktom jest jednak możliwe stwierdzenie, że zarówno ten element, jak i pozostałe części pilastrów pokrywała płaskorzeźbiona, delikatna arabeska kandelabrowa. Motywy roślinne tworzące dekorację są wprawdzie z trudem już rozpoznawalne, udaje się jednak jeszcze rozróżnić pionową wić z charakterystycznym, trójlistnym pierścieniem, oddzielającym kolejne piętra kandelabru, oraz symetrycznie rozchodzące się listki i odrosty. Ich kształty, mimo iż bardzo już zatarte, pozwalają docenić dawną precyzję rysunku i niezwykle staranne wykonanie dzieła, z zachowaniem wypukłości i pogrubień w miejscach bujniejszego listowia oraz z delikatniejszym oddaniem wąskich i cienkich łodyżek.

O niegdysiejszej wysokiej klasie zabytku świadczą też inne szczegóły. Jest to przede wszystkim realistycznie rzeźbiony wizerunek Baranka, leżącego na księdze, ukazanej w poprawnie ujętym skrócie perspektywicznym, z zaznaczonym rysunkiem rozdzielonych zakładkami stronnic. Kolejnym wyróżniającym elementem są umiejętnie odkute piękne profile obramień.

Pierwotne przeznaczenie odnalezionych reliktów jest dyskusyjne. Pomijając niewłaściwe użycie przez inwentaryzatorki terminu „sakramentarium” (autorki miały zapewne na myśli „sakrarium”) ${ }^{16}$, istniejące fragmenty są zbyt małe,

robiono w dostępie do magazynu, uniemożliwiły mi powtórne obejrzenie zabytku w późniejszym czasie. Jego dzisiejszy wygląd jest mi nieznany.

15 Zob. fotografie: Narodowy Instytut Dziedzictwa, Karta ewidencji zabytków ruchomych: Czerwińsk, Klasztor, Lapidarium, Fragment obramienia, nr PLX 000 ooo 256, oprac. B. Bieniewska, 28.09.1962; oraz Katalog zabytków..., dz. cyt., il. 158.

16 Określenie „sakramentarium” jest stosowane dla tabernakulum w kształcie wolnostojącej lub przyściennej wieży stojącej na posadzce kościoła. W literaturze niemieckiej dla takiej formy istnieje nazwa Sakramentshäuschen, co należałoby tłumaczyć jako „domek na sakrament” lub „domek eucharystyczny”. Por. H. Weidenhöffer, Sakramentshäuschen in Österreich. Eine Untersuchung zur Typologie und stilistischen Entwicklung in der Spätgotik und Renaissance, Graz 1992, passim; 
by można było $\mathrm{z}$ całą pewnością uznać je za części takiego schowka. Jeśli jednak przyjąć tę hipotezę za słuszną, należy zwrócić uwagę na usytuowanie półkolistej płyciny z Barankiem w obrębie zachowanego reliktu. Taki element o niewielkich rozmiarach mógł w tabernakulum ściennym stanowić tympanon nad sportellem, a nie, jak przyjęły badaczki, zwieńczenie całości. Uznaniu go, za autorkami Katalogu zabytków, za zwieńczenie całej konstrukcji przeczy też relikt pilastra, wychodzący ponad krzywiznę obramienia (niezachowany już, jednak udokumentowany $\mathrm{w}$ trakcie inwentaryzacji, dokonanej przez badaczki ${ }^{17}$. Ujmował on nie tylko omawiany tympanon, ale także, nieistniejącą obecnie, część płyty powyżej jego półkolistego obramienia. Owa część płyty pomiędzy pilastrem i krzywizną tympanonu stanowiła przyłucze ${ }^{18}$, zapewne pierwotnie ograniczone od góry architrawem lub tylko gzymsem. Właściwe zwieńczenie, jeśli było przewidziane, musiało znajdować się powyżej. Relikt pilastra, istniejący do niedawna po lewej stronie tympanonu wskazuje, że konstrukcja była edikulą. Taki sam pilaster musiał się znajdować po drugiej stronie. Pilastry ujmowały niszę, która, jak można sądzić z profilowanego obramienia, była bardzo płytka. Duży, nierozczłonkowany i pozbawiony dekoracji fragment kamienia pod dolną krawędzią tympanonu wskazywałby, że sportello zostało umieszczone w dolnej części obramienia, bardzo nisko. Pustą powierzchnię ponad otworem mogła wypełniać tablica z inskrypcją odnoszącą się do funkcji schowka (il. 7, 8b).

Przyjmując dla odnalezionych szczątków pierwotną funkcję sakrarium, trzeba wskazać inne zachowane dzieło, do którego budowa omawianego zabytku czerwińskiego mogła być podobna. Wśród znanych mi tabernakulów południowoeuropejskich i polskich schemat najbardziej zbliżony do zrekonstruowanego powyżej ma struktura sakrarium w Gdowie, łączonego z warsztatem czynnego

J. Nowiński, Ars Eucharistica. Idee, miejsca i formy towarzyszace przechowywaniu eucharystii w sztuce wczesnochrześcijańskiej i średniowiecznej, Warszawa 200o, s. 194. W źródłach średniowiecznych pojawiały się określenia: armarium, armariolum, armatrium, cyborium, conditorium, cophinus, custodia, fenestella, repositorium, sacrarium, tabernaculum. Por. F. Raible, Der Tabernakel einst und jetzt, Freiburg im Breisgau 1908, s. 172; J. Nowiński, Ars Eucharistca..., dz. cyt., s. 172. Natomiast termin „sakrarium”, względnie „tabernakulum ścienne” (Wandtabernakel), jest używany dla określenia schowka ściennego, służącego przechowywaniu Eucharystii. Zob. publikacje na ten temat: F. Raible, Der Tabernakel..., dz. cyt., s. 172-181; H. Caspary, Das Sakramentstabernakel in Italien bis zum Konzil von Trient. Gestalt, Ikonographie und Symbolik, kultische Funktion, München 1964, s. 8-9; O. Nußbaum, Die Aufbewahrung der Eucharistie, Bonn 1979, s. 385-426; J. Nowiński, Ars Eucharistca..., dz. cyt., s. 172-174.

${ }_{17}$ Zob. Katalog zabytków..., dz. cyt., il. 158.

18 Przyłucza były zachowane jeszcze w 1962 roku. Por. fot. na karcie ewidencyjnej w Narodowym Instytucie Dziedzictwa. 
wcześniej w kaplicy Zygmuntowskiej Giovanniego Ciniego i datowanego na drugą ćwierć Xvı wieku ${ }^{19}$ (il. 8a, b). Oprawę architektoniczną w Gdowie stanowi edikula z pilastrami ujmującymi płytką arkadę ze sportellem ulokowanym w dolnej części. Również motywy arabeskowe tego sakrarium są podobne do stwierdzonych w reliktach czerwińskich. W Gdowie na skutek wielokrotnego malowania na olejno, a następnie czyszczenia i zdzierania warstw farby, większość motywów arabeskowych zatraciła precyzję rysunku, ale uważniejsze oględziny nie pozostawiają wątpliwości co do pierwotnego stanu arabeski. Była ona rzeźbiona plastycznie i modelowana wieloplanowo. Wypełniającą pilastry wić roślinną w układzie kandelabrowym cechowało bogactwo kształtów, zauważalne nadal, pomimo zatarcia i spłaszczenia form. Analogią dla tych motywów są dekoracje w kaplicy Zygmuntowskiej.

Odmienna w obu sakrariach jest płaskorzeźba w tympanonie: w Gdowie umieszczono tondo z przedstawieniem Chrystusa w typie Salvatoris mundi, w Czerwińsku zaś tympanon wypełnia wyjątkowe w dekoracjach tabernakulów ściennych wyobrażenie Baranka Apokaliptycznego. Ponadto inny charakter ma profilowane obramienie. $Z$ kolei rozmiary tympanonów w porównywalnych ze sobą fragmentach obudowy wykazują bardzo dużą zbieżność. Tym bardziej zastanawia w Czerwińsku pusta płaska powierzchnia poniżej tympanonu. W Gdowie jest w tym miejscu tylko dość wąska płycina i pod nią sportello.

Nie jest znane pierwotne miejsce, do którego miało być przeznaczone domniemane sakrarium czerwińskie. W dużym, trójnawowym kościele było to najpewniej prezbiterium, a ściślej jego lewa strona - strona Ewangelii. Tam bowiem tradycyjnie w czasach przedtrydenckich sytuowano wnęki ze schowkiem na Najświętszy Sakrament ${ }^{20}$. Powstanie omawianej oprawy architektonicznej w Czerwińsku można, $\mathrm{z}$ uwagi na wczesne zastosowanie antykizujących form detalu, łączyć z renesansową przebudową kościoła i klasztoru w latach

19 Zob. F. Kopera, Materiały do inwentaryzacji zabytków sztuki i kultury w Polsce. Zabytki kościoła parafialnego w Gdowie, „Wiadomości Numizmatyczno-Archeologiczne” 3 (1905) t. 63, nr 5, szp. 309-312; S. Cercha, F. Kopera, Nadworny malarz Zygmunta Starego Giovanni Cini ze Sieny i jego dzieła w Polsce, Kraków 1916, s. 90-91, il. 92; M. Kornecki, Zabytki sztuki, [w:] Monografia powiatu myślenickiego, cz. 1: Historia, Kraków 1970, s. 339-340; T. Chrzanowski, M. Kornecki, Sztuka ziemi krakowskiej, Kraków 1982, s. 250; E. Korpysz, Ренесансни кивоти в Малопольщі та на Львівщині, [w:] Історія релігій в Үкраїні. Праці ххг-ї міжнародної наукової конференції, т. 2, Львів 2012, s. 540-552.

${ }^{20}$ Zob. E. Korpysz, Zmiany w sposobie przechowywania Eucharystii w świetle działalności bp. Gian Mattea Gibertiego oraz potrydenckich reform św. Karola Boromeusza i późniejszych synodów, [w:] Sztuka po Trydencie. Studia de Arte Moderna I. Studia dedykowane Prof. Adamowi Małkiewiczowi, red. K. Kuczman, ks. A. Witko, Kraków 2014, s. 39-54. 
1524-1538. Ale w odróżnieniu od innych kamiennych detali i obramień portalowych, zachowanych $\mathrm{w}$ obrębie zabudowań konwentu, dekoracja oprawy domniemanego sakrarium jest zaawansowana stylowo i bliska wzorom włoskim, znanym z Krakowa. Profile simy i półwałka były odkute precyzyjne, z zachowaniem właściwych proporcji, arabeska na pilastrach miała delikatny rysunek. Również Baranek, ułożony na księdze, ukazanej w prawidłowo wykreślonej perspektywie, jest rzeźbą zdecydowanie nowożytną. Fragmentów sakrarium nie można zatem wiązać $\mathrm{z}$ warsztatem kamieniarskim odkuwającym na zlecenie opata Kuli obramienia portali. Do wykonania tej oprawy został zaangażowany inny, lepszy rzeźbiarz. Duże podobieństwo dekoracji pilastrów do tego samego typu ornamentów w Gdowie (gdzie, jak wspomniano, uległy zeszlifowaniu), a zwłaszcza zbliżenie detalu do motywów w kaplicy Zygmuntowskiej, wskazują na artystę, któremu prawdopodobnie były znane z autopsji wzory współczesnej kamieniarki wawelskiej. Kamieniarz, który dostarczył elementy obramienia, nie tylko znał podobne rozwiązania, ale był biegły w ich realizacji, mógł więc być nawet zaangażowany bezpośrednio do prac w katedrze krakowskiej. Wczesne zastosowanie w Czerwińsku motywów renesansowych, odkutych prawidłowo, umiejętnie i precyzyjnie i wyróżniających się wśród innych, zachowanych w klasztorze elementów kamieniarki (o tradycjach jeszcze gotyckich), może dowodzić pojawienia się w opactwie nowej grupy rzemieślników, o większych zdolnościach.

Opat Kula był znany ze swojej przedsiębiorczości i operatywności. Skutecznie zabiegał u króla Zygmunta Starego i u księcia Janusza Mazowieckiego o różne przywileje dla konwentu. Między innymi w roku 1525 uzyskał zwolnienie od opłat za towary przewożone Wisłą między Gdańskiem, Toruniem, Krakowem i Czerwińskiem ${ }^{21}$. Tą drogą mogły docierać do opactwa zarówno materiały niezbędne w trakcie prac remontowych, jak też gotowe elementy do wyposażenia świątyni i klasztoru. Opat utrzymywał ponadto ożywione i ścisłe kontakty z kapitułą i biskupami płockimi. Jego rządy i prace budowlane, prowadzone wtedy w klasztorze, zbiegły się w czasie z budową katedry w Płocku. Biskup płocki Andrzej Krzycki kontraktem z grudnia 1531 roku zaangażował do tego dzieła wybitnych fachowców, pracujących uprzednio w warsztacie Berecciego: Bernardyna de Gianotisa, Jana Ciniego i Flipa z Fiesole ${ }^{22}$. W 1532 roku Jan Cini

${ }^{21}$ Zob. H. Folwarski, Poczet..., dz. cyt., s. 21-22.

${ }_{22}$ Zob. W. Budka, Działalność architektów i rzemieślników przy restauracjach katedry płockiej w wieku XVI, „Rzeczy Piękne” 5 (1925), s. 125-126; H. Kozakiewiczowa, Spótka architektoniczno-rzeźbiarska Bernardina de Gianotis i Jana Cini, „Biuletyn Historii Sztuki” 21 (1959) nr 2, s. 152-153. 
wrócił do Polski z trzyletniego pobytu w Sienie i mógł podjąć się realizacji nowych zamówień ${ }^{23}$. W trakcie wznoszenia katedry Włosi utrzymywali warsztat kamieniarsko-rzeźbiarski w Krakowie i sprowadzali kamieniarkę oraz detal architektoniczny do Płocka Wisłą. Na miejscu zaś do podrzędniejszych prac wykorzystywali tutejszą siłę roboczą, dysponującą niższymi kwalifikacjami ${ }^{24}$. Budowa katedry trwała niemal do końca 1534 roku. Niewykluczone, że Jakub Kula, dokonując w tym samym czasie remontu klasztoru, uwzględnił obecność Włochów w Płocku i skorzystał z ich doświadczeń w zakresie zaprojektowania wzoru, doboru motywów ornamentalnych i samego wykonania dzieła. Nie musiało ono wyjść w całości bezpośrednio spod ręki któregoś z trzech wymienionych wyżej rzeźbiarzy, ale mogło powstać pod ich kierunkiem lub przy dużym udziale osobistym. Wskazywałyby na to włoskie w formie detale i ich wysoka klasa, dostrzegalna mimo fragmentarycznego zachowania elementów sakrarium. Wprawdzie wśród motywów zdobniczych wyróżnia się, poza arabeską, Baranek Apokaliptyczny, niespotykany w zachowanych sakrariach z okolic Krakowa, niestosowany też w stanowiących dla nich wzór ściennych tabernakulach włoskich i węgierskich. Jednak ideę umieszczenia motywu Baranka w zamawianym sakrarium można przypisać inicjatywie samego zleceniodawcy. Natomiast i ten projekt został zrealizowany przez biegłego rzeźbiarza, czego dowodem są dobre proporcje i umiejętne odtworzenie sylwetki zwierzęcia, a przede wszystkim prawidłowe zastosowanie perspektywy - nowatorskiego wówczas na tym obszarze sposobu przedstawiania rzeczywistości.

Zachowane $\mathrm{w}$ lapidarium czerwińskim relikty kamieniarskie można uznać za dzieło krakowskie. Twórcy trzeba szukać w warsztacie artystów włoskich, zaangażowanych w pracach na Wawelu i przy katedrze w Płocku, $z$ której renowacją należałoby wiązać czas powstania interesującego nas zabytku. Jeśli omawiane detale należą do sakrarium, to, jako powstałe w początkach lat 30. XVI wieku, byłoby ono jednym z najwcześniejszych tego typu obiektów w Rzeczypospolitej i w swojej formie odosobnionym na terytorium Mazowsza.

${ }^{23}$ Zob. J. Ptaśnik, Cracovia Artificum 1501-1550, z. 1, do druku przygot. M. Friedberg, Kraków 1936, s. 245, nr 657 (Źródła do Historii Sztuki i Cywilizacji w Polsce, 5); H. Kozakiewiczowa, Spółka architektoniczno-rzeźbiarska..., dz. cyt., s. 151-173.

${ }^{24}$ Zob. H. Kozakiewiczowa, Spółka architektoniczno-rzeźbiarska..., dz. cyt., s. 154. 


\section{Bibliografia}

Budka W., Działalność architektów i rzemieślników przy restauracjach katedry płockiej w wieku XVI, „Rzeczy Piękne” 5 (1925), s. 125-126.

Caspary H., Das Sakramentstabernakel in Italien bis zum Konzil von Trient. Gestalt, Ikonographie und Symbolik, kultische Funktion, München 1964.

Cercha S., Kopera F., Nadworny malarz Zygmunta Starego Giovanni Cini ze Sieny i jego dzieła $w$ Polsce, Kraków 1916.

Chrzanowski T., Kornecki M., Sztuka ziemi krakowskiej, Kraków 1982.

Folwarski H., Poczet opatów klasztoru kanoników regularnych w Czerwińsku, „Nasza Przeszłość. Studia z Dziejów Kościoła i Kultury Katolickiej w Polsce” Kraków, 6 (1957), s. $5-81$.

Katalog Zabytków Sztuki w Polsce,, t. 10: Dawne województwo warszawskie, z. 16: Płońsk i okolice, oprac. I. Galicka, H. Sygietyńska, T. Mroczko, Warszawa 1979.

Kopera F., Materiały do inwentaryzacji zabytków sztuki i kultury w Polsce. Zabytki kościoła parafialnego w Gdowie, „Wiadomości Numizmatyczno-Archeologiczne” 3 (1905) t. 63, nr 5, szp. 309-312.

Kornecki M., Zabytki sztuki, [w:] Monografia powiatu myślenickiego, cz. 1: Historia, Kraków 1970, s. 339-340.

Korpysz Е., Ренесансни кивоти в Малопольщі та на Львівщині, [w:] Історія релігій в Үкраїні. Праці ххг-ї міжнародної наукової конференцї, т. 2, Львів 2012, s. 540-552. Korpysz E., Zmiany w sposobie przechowywania Eucharystii w świetle działalności bp. Gian Mattea Gibertiego oraz potrydenckich reform św. Karola Boromeusza i późniejszych synodów, [w:] Sztuka po Trydencie. Studia de Arte Moderna I. Studia dedykowane Prof. Adamowi Małkiewiczowi, red. K. Kuczman, ks. A. Witko, Kraków 2014, s. 39-54. Kozakiewiczowa H., Spółka architektoniczno-rzeźbiarska Bernardina de Gianotis i Jana Cini, „Biuletyn Historii Sztuki” 21 (1959) nr 2, s. 151-174.

Mroczko T., Czerwińsk romański, Warszawa 1972.

Mroczko T., Polska sztuka przedromańska i romańska, Warszawa 1988.

Nowiński J., Ars Eucharistica. Idee, miejsca i formy towarzyszace przechowywaniu eucharystii w sztuce wczesnochrześcijańskiej i średniowiecznej, Warszawa 2000.

Nowiński J., Czerwińsk, Warszawa 2012.

Nußbaum O., Die Aufbewahrung der Eucharistie, Bonn 1979.

Polska sztuka przedromańska i romańska do schyłku XIII wieku, t. 1-2, red. M. Walicki, Warszawa 1971.

Ptaśnik J., Cracovia Artificum 1501-1550, z. 1, do druku przygot. M. Friedberg, Kraków 1936 (Źródła do Historii Sztuki i Cywilizacji w Polsce, 5).

Raible F., Der Tabernakel einst und jetzt, Freiburg im Breisgau 1908. 
Szablowski J., Architektura renesansowa i manierystyczna w Polsce, Kraków 1965. Świechowski Z., Świechowska E., Polska sztuka romańska, Warszawa 2006. Weidenhöffer H., Sakramentshäuschen in Österreich. Eine Untersuchung zur Typologie und stilistischen Entwicklung in der Spätgotik und Renaissance, Graz 1992.

\begin{abstract}
Abstrakt
Wzniesiony przed połową XII wieku kościół i klasztor Kanoników Regularnych Lateraneńskich w Czerwińsku został przebudowany w latach 1524-1538 z inicjatywy opata Jakuba Kuli. Założono wówczas sklepienia w kościele, powstała polichromia w prezbiterium i dekoracja żeber sklepiennych w refektarzu klasztornym. Okna i portale otrzymały kamienne, profilowane obramienia o formach przejściowych, gotycko-renesansowych. Z tego czasu pochodzą też, bardzo już dziś zniszczone, pozostałości kamiennej oprawy sakrarium - relikty pilastrów dekorowanych delikatnie i precyzyjnie rzeźbioną arabeską kandelabrową oraz fragment tympanonu z motywem Baranka leżącego na księdze i zbierającego krew do kielicha. W odróżnieniu od innych detali i obramień dekoracja sakrarium jest zaawansowana stylowo i bliska wzorom włoskim, znanym z Krakowa. Wysoka klasa obiektu, widoczna pomimo szczątkowego zachowania, wskazuje na biegłego artystę. Wspólne motywy ornamentów kierują naszą uwagę w stronę innego podobnego obiektu, sakrarium w Gdowie, wykonanego prawdopodobnie w drugiej ćwierci XVI wieku w warsztacie Giovanniego Cini ze Sieny, zatrudnionego wcześniej w kaplicy Zygmuntowskiej.

Prace budowlane w Czerwińsku zbiegły się w czasie z budową katedry w Płocku, prowadzonej przez Bernardina de Gianotis, Giovanniego Cini i Filipa z Fiesole. W 1532 roku Cini wrócił do Polski z trzyletniego pobytu w Sienie i mógł podjąć się realizacji nowych zamówień. Niewykluczone, że opat Kula, dokonując w tym samym czasie remontu klasztoru, uwzględnił obecność Włochów w Płocku i skorzystał z ich doświadczeń w zakresie zaprojektowania wzoru, doboru motywów ornamentalnych i samego wykonania dzieła.
\end{abstract}

\title{
Słowa kluczowe
}

klasztor w Czerwińsku, rzeźba renesansowa, sakrarium, Giovanni Cini 


\begin{abstract}
Changes to the architectural and sculptural furnishings of monastery in Czerwińsk in the first half of the XVI century
\end{abstract}

The church and the monastery of the Canons Regular of the Lateran in Czerwińsk was erected before the first half of the XII century and rebuilt in the years 1524-1538, on the initiative of the abbot Jakub Kula. Following the reconstruction, the church gained vaults and polychrome decoration in the chancel, windows and portals received profiled stone frames with transitional Gothic-Renaissance forms, while the refectory of the monastery was decorated with rib vault. The remains of the stone framing of the sacrarium, today in a badly damaged state, originate from this period as well. They include the relics of finely decorated pilasters, precisely carved arabesque candelabra and a part of the tympanum with the motif of the lamb lying on the book and collecting the blood into the cup. Unlike other details and framings, the decoration of sacrarium is advanced in terms of style and close to the Italian motives and patterns, known from Kraków. Such elements are a proof of the high class of the monument, visible despite its damaged state, and show the expertise of the artist. Similarities of the ornament direct our attention toward another object, the sacrarium in Gdów, built probably in the second quarter of the XVI century, in the workshop of Giovanni Cini of Siena, employed earlier in the constructions of Sigismund Chapel in Kraków (kaplica Zygmuntowska).

Renovation works in Czerwińsk coincided with the construction of the cathedral in Płock, led by Bernardino de Gianotis, Giovanni Cini and Filippo of Fiesole. In 1532, Cini returned to Poland after a three-year stay in Siena, and could take on new orders. It is possible that the abbot Kula, who commissioned the renovation of the monastery at this time, aware of the presence of Italians in Płock, took advantage of their experience in design, selection of ornamental motifs and their expertise in the execution of the work itself.

\title{
Keywords
}

monastery of Czerwińsk, Renaissance sculpture, sacrarium, Giovanni Cini 

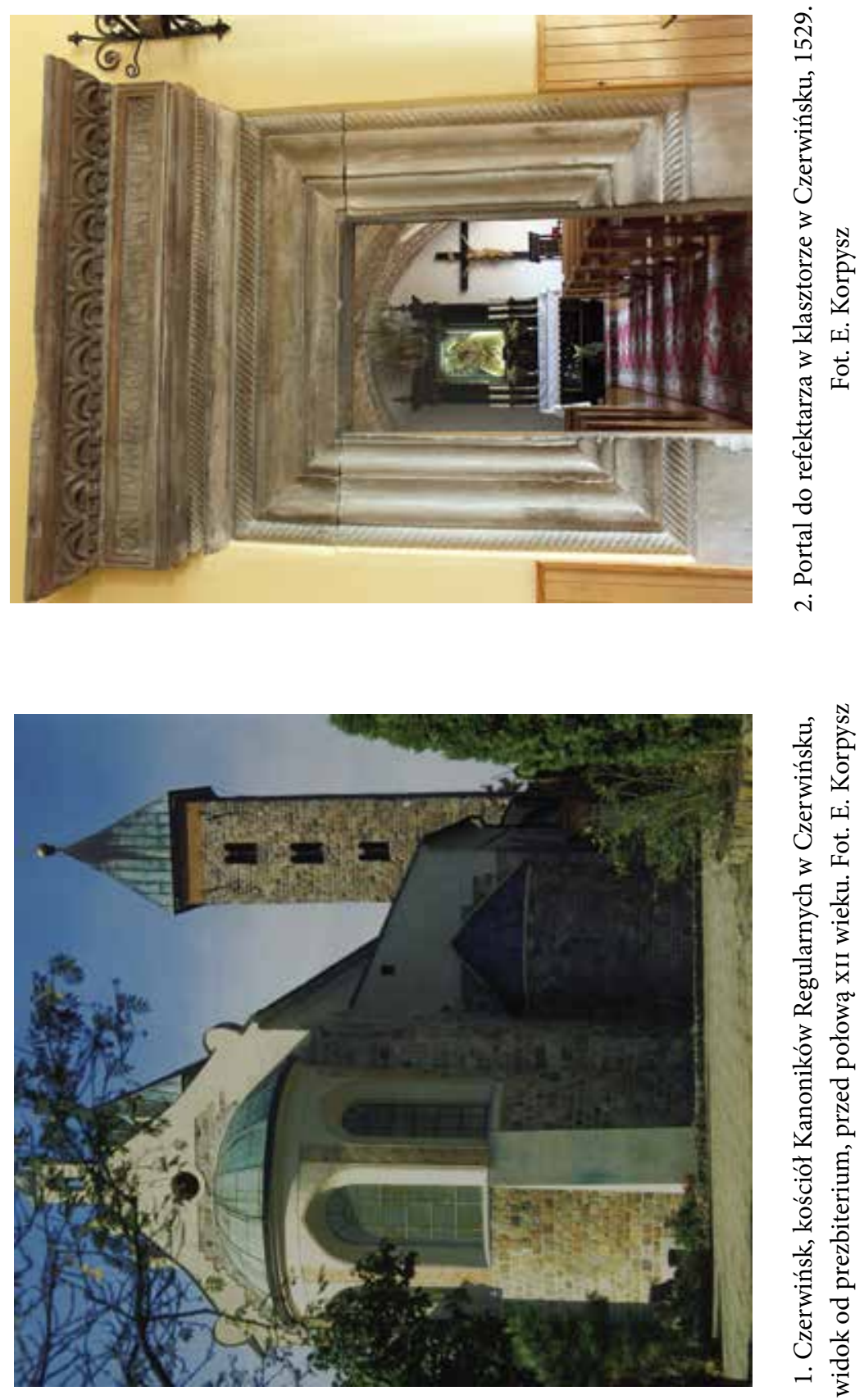


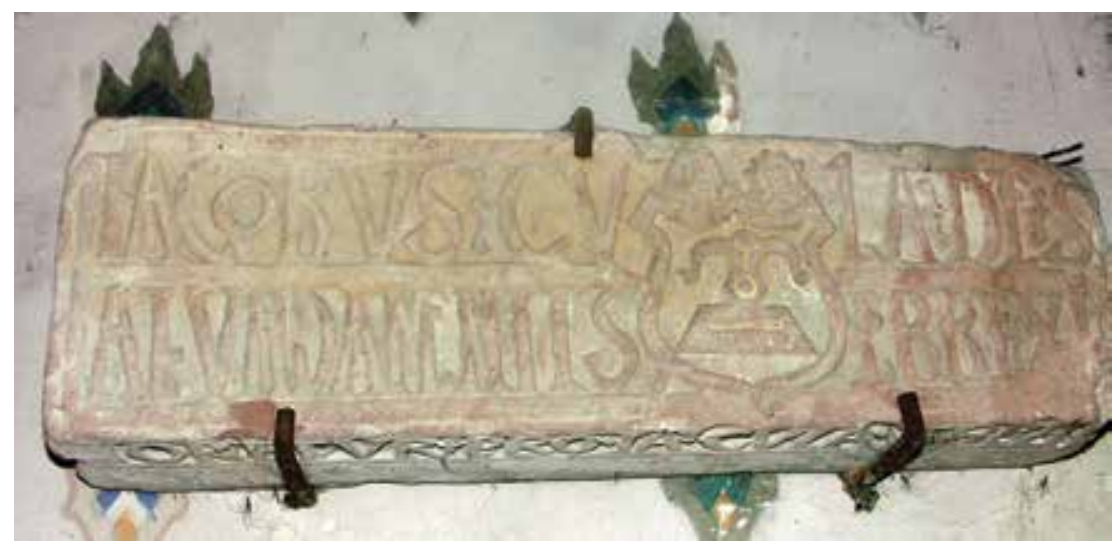

3. Relikt nadproża w lapidarium w kruchcie kościoła klasztornego w Czerwińsku, po 1524 roku. Fot. E. Korpysz

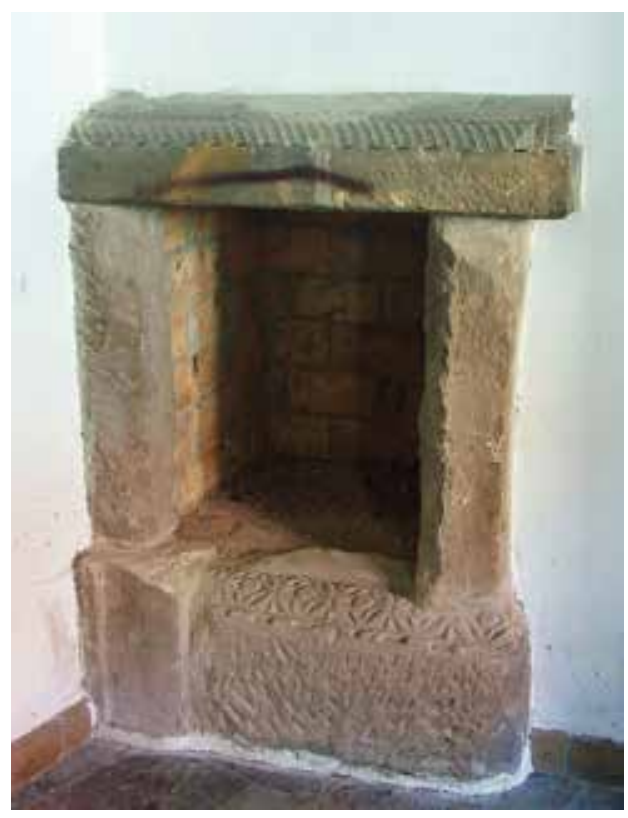

4. Kominek w klasztorze w Czerwińsku, po 1524 roku. Fot. E. Korpysz 

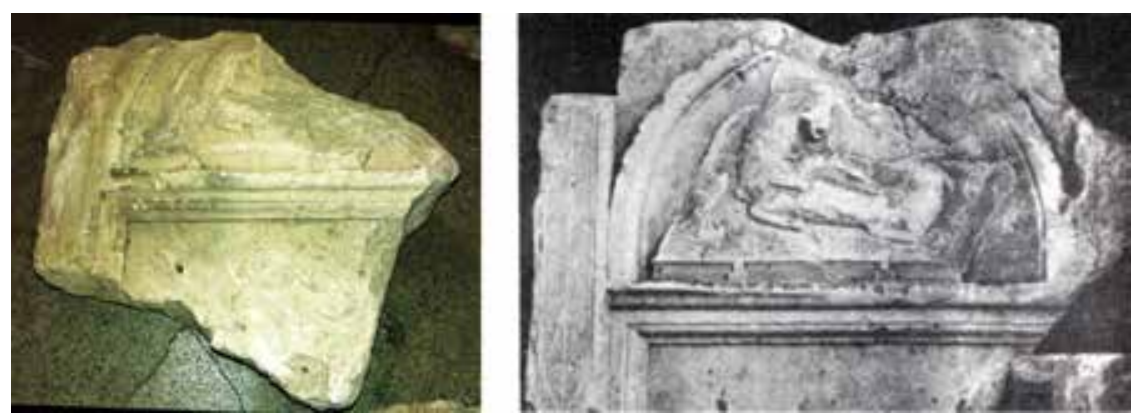

5a. Fragment tympanonu z przedstawieniem Baranka, lapidarium klasztorne w Czerwińsku, początek lat 30. Xvi wieku; stan z 2006 roku. Fot. E. Korpysz 5b. Fragment tympanonu z przedstawieniem Baranka, lapidarium klasztorne w Czerwińsku, początek lat 30. xvi wieku; stan z 1979 roku. Fot. ze zbiorów IS PAN w Warszawie
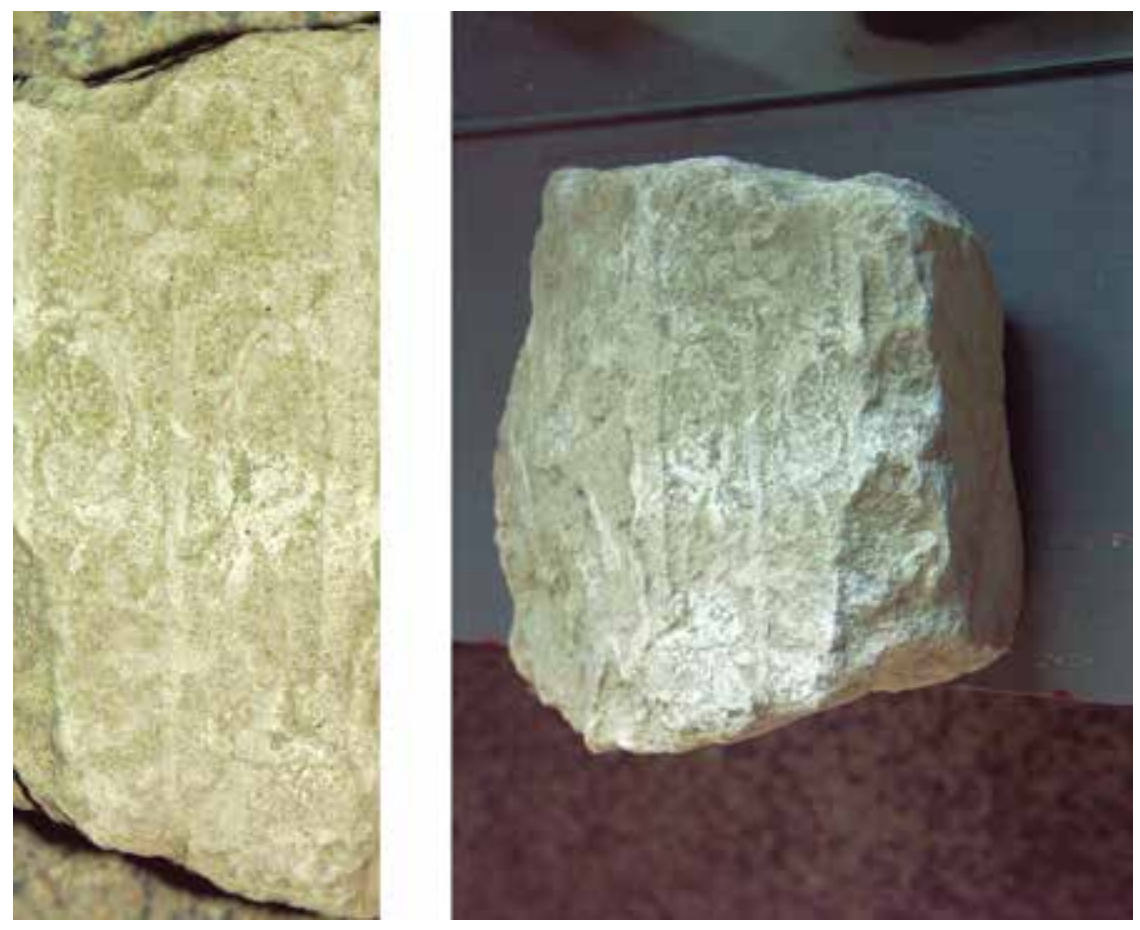

6a, b. Relikty pilastrów z motywem arabeski, początek lat 30. Xvi wieku, lapidarium klasztorne w Czerwińsku. Fot. E. Korpysz 


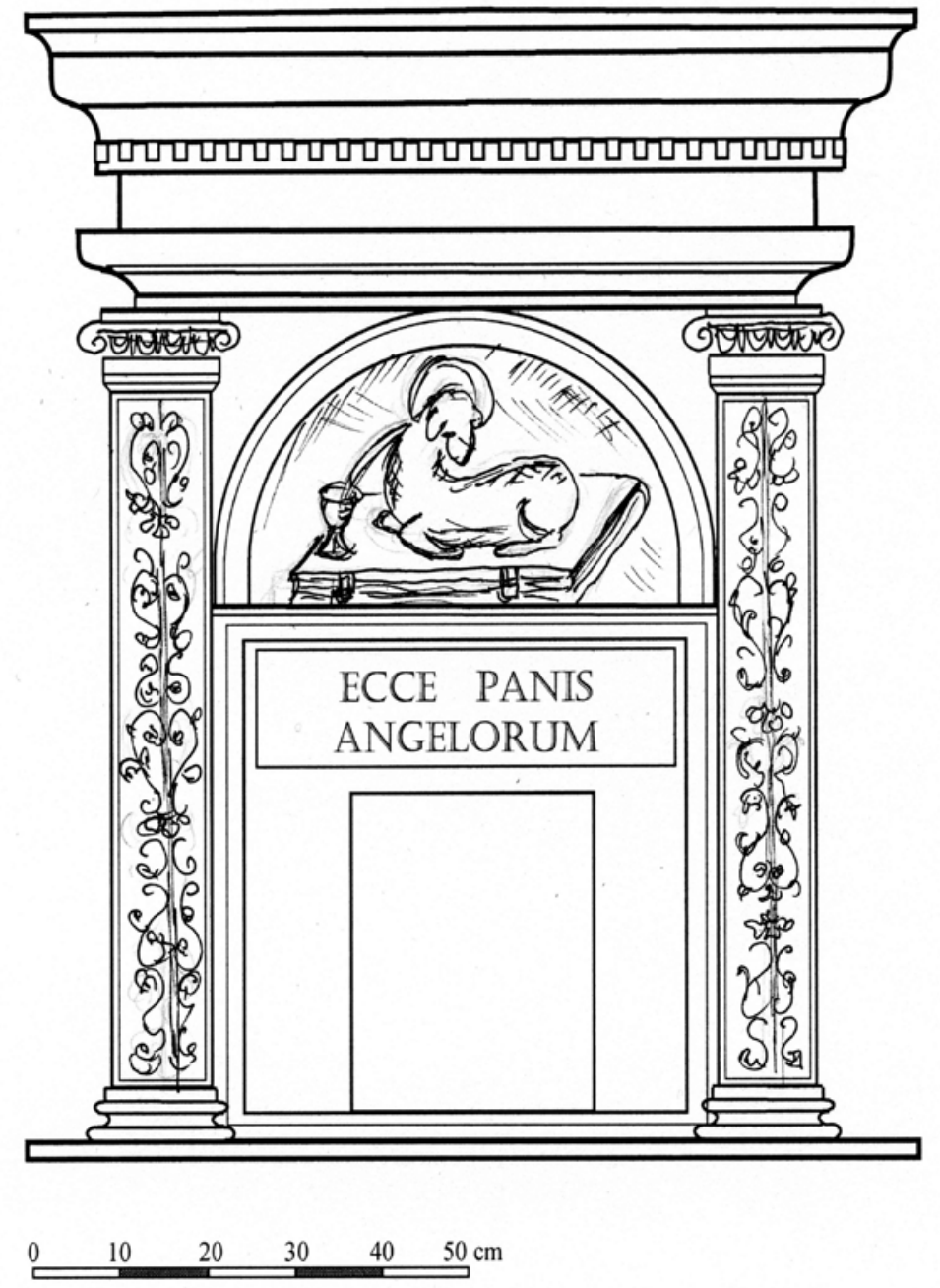

7. Rekonstrukcja rysunkowa wyglądu sakrarium z kościoła Kanoników Regularnych w Czerwińsku, początek lat 30. Xvı wieku. Rys. E. Korpysz 

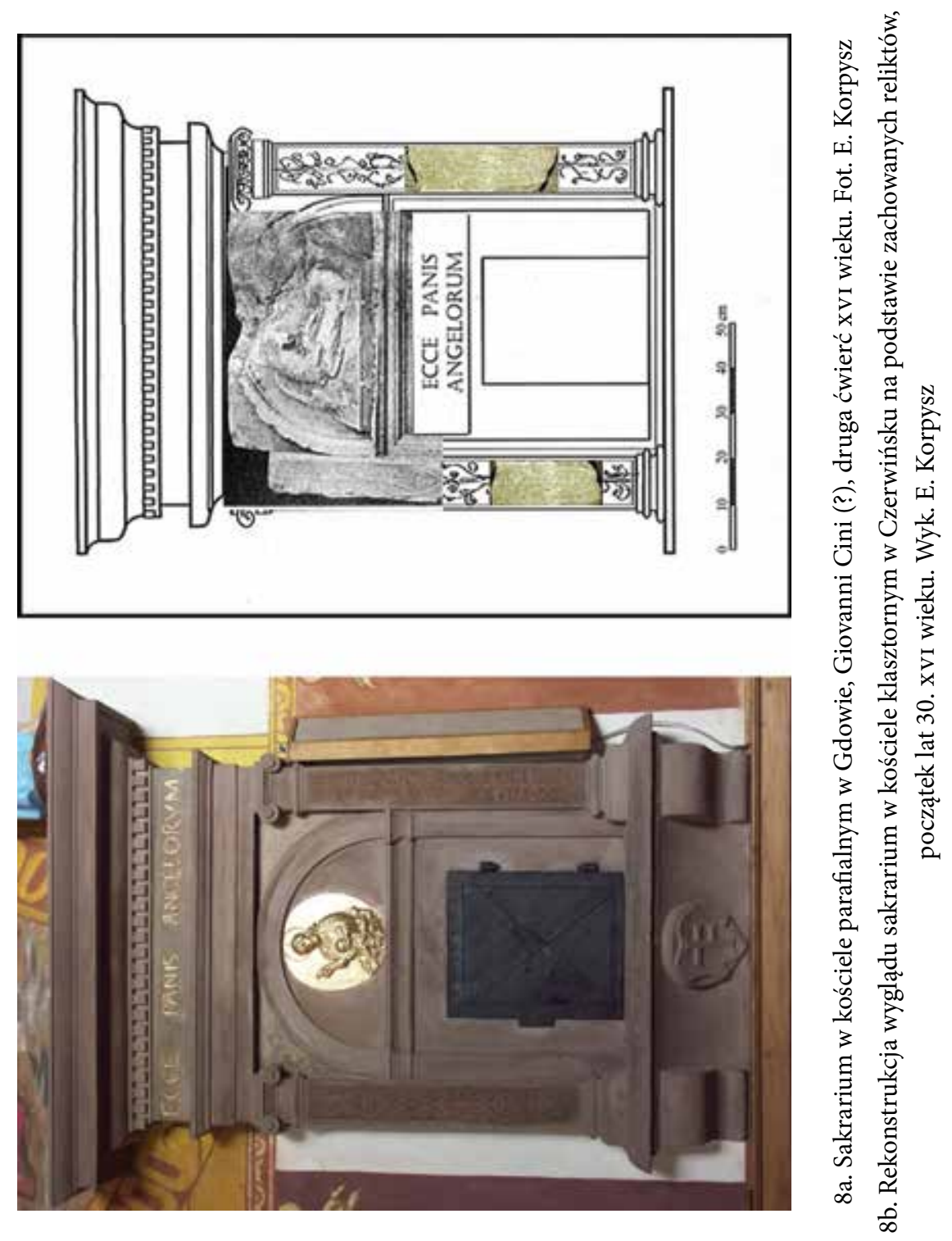